\title{
EFFECTIVENESS OF CHILD TO CHILD PROGRAM ON KNOWLEDGE REGARDING ILL EFFECTS OF TELEVISION WATCHING AMONG SCHOOL CHILDREN
}

\author{
Mrs. G. Brindha Mary ${ }^{*}$ | Dr. S. S. Sharmila Jansi Rani*
}

*Assistant Professor, Thasiah College of Nursing, Marthandam, Tamil Nadu, India.

**Vice Principal, Christian College of Nursing, Neyyoor, Tamil Nadu, India. DOI: http://doi.org/10.47211/tg.2020.v07iws01.008

Received $14^{\text {th }}$ June 2020, Accepted $20^{\text {th }}$ June 2020, Available online $30^{\text {th }}$ June 2020.

\section{ABSTRACT:}

A pre experimental one group pre test post test design was adopted to evaluate the child to child program on Knowledge regarding ill effects of television watching among school children. Sixty school children were selected using simple random sampling. Pre test conducted by using structured knowledge questionnaire. Child to child program was given by the change agents for 4 weeks. The results showed that child to child program was effective to improve knowledge at ' $p$ ' value was $<0.001$; it signifies the effectiveness of child to child program on knowledge regarding ill effects of television watching.

KEYWORDS: Child to child program, III effects, Television watching and school children etc.

\section{ABOUT AUTHORS:}

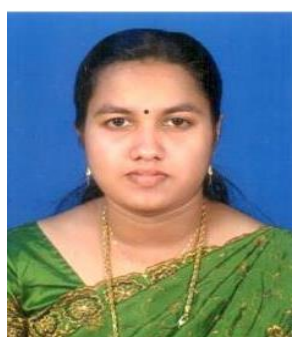

Author Mrs. G. Brindha Mary is an Assistant Professor of Thasiah College of Nursing, Marthandam, Tamil Nadu, India.

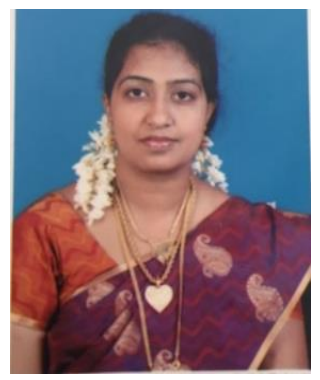

Author Prof. Dr. S. S. Sharmila Jansi Rani is Vice Principal at Christian College of Nursing, Neyyoor in Kanyakumari District of Tamil Nadu, India. 


\section{INTRODUCTION:}

Television watching is an enjoyable activity for the children. It is the window of the world. From the past few decades television has crawled to Indian homes. Accessibility to television is on increase day by day and has been accepted by the society. Varieties of programmes like News, Sports, Educative, Entertainment, Cartoon etc. are available round the clock. These are especially designed to attract all sectors of society, specially the children. Children who watch television too much have several bad effects among this; first effect is to their cognitive development.

Children who watch television programmes can be lack of concentration. The second effect is to their health. The child who likes to watch television programs can be in front of it many hours. If the children watch television programs too much, they will have a problem with their eyes, overweight, etc. The third effect is their habit. They become lazy to do something else such as study because they do not want to miss the television programs. It will influence their intelligence. Another bad effect to their habit is they will be influences a violence in some television programs because they have not been able to think long and think what is better or bad. In brief, watching TV programs too much will give bad effects to the children.

Ninety eight per cent of households have at least one television set and many children have their own set in bedrooms. It is extremely unlikely that any child will be denies the opportunity to watch television. The children who watches too much cartoons on television are more likely to have a mental and psychological effects. From school age up to their graduation and a child watches television around 18,000 hours. This comparison is an outrage because of the amount of television that is watched by a child will have an effect on their brain, emotions and their sense to feel pain.

\section{STATEMENT OF THE PROBLEM:}

A study to assess the effectiveness of child to child program on knowledge regarding ill effects of television watching among school children in Kids Oxford Matriculation Higher Secondary School, Kuzhithurai at Kanyakumari District.

\section{OBJECTIVES:}

- To assess and compare the pre test and post test score on knowledge regarding ill effects of television watching among school children.

- To determine the effectiveness of child to child program on knowledge regarding ill effects of television watching among school children.

- To find out the association between the post tests level of knowledge regarding ill effects of television watching with selected socio demographic and clinical variables.

\section{HYPOTHESES:}

$\mathrm{H}_{1}$ - There will be a significant difference between pre test and post test score on knowledge regarding ill effects of television watching among school children.

$\mathrm{H}_{2}$ - There will be significant association between the post test score on knowledge regarding ill effects of television watching among school children with selected socio demographic and clinical variables.

\section{METHODOLOGY:}

The study utilized pre experimental one group pre test post test design. Children those who were studying $7^{\text {th }}$ and $8^{\text {th }}$ std in Kids Oxford Matriculation Higher Secondary School who fulfilled the inclusive criteria were selected. 60 samples were selected by using simple random technique.

Two tools were used in this study.

Tool 1: Socio demographic Proforma consisted of items on background data of the participants. It included age, sex, grade of the child, birth order of the child, type of family, family income per month, occupation of father, occupation of mother and place of living. Clinical Proforma were academic performance of child, duration of television watching, previous knowledge about ill effects of television watching and sources of information.

Tool 2: Structured knowledge questionnaire was constructed for the students in the form of multiple choice questions. It consisted of 30 items, in that 10 questions for healthy practices of television watching and 20 questions for ill effects of television watching. Score of 1 is allotted for each correct answer and score of 0 was allotted for each incorrect answer. The total maximum and minimum score were 30 and 0 respectively.

After obtaining initial permission and formal approval from the School Authorities were selected 6 change agents based on their academic excellence, their interest and willingness. Teaching was given by the researcher using power point presentation. Those children were prepared as a change agent. 


\section{ARTICLES}

60 students selected by simple random sampling technique. The nature and purpose of the study was explained to the children. Pre test was conducted by using structured knowledge questionnaire. 60 samples were divided into 6 subgroups. Each group of 10 students were educated regarding ill effects of television watching by the 6 change agents who underwent health education classes by the investigator already. Post test was administered after 7 days of child to child program. The same knowledge questionnaire was used to collect the post test data.

\section{RESULTS \& DISCUSSIONS:}

During pre test level of knowledge regarding ill effects of television watching indicated that majority of the school children $63.33 \%$ had moderately adequate knowledge, $36.67 \%$ had inadequate knowledge and no one had adequate knowledge. Whereas the post test level of knowledge indicates that, $68.33 \%$ had adequate knowledge, $31.67 \%$ had moderately adequate knowledge and no one had inadequate knowledge.

In pre test mean value was 13. 61 with standard deviation of 2.04. Where as in post test mean value was 24.92 with standard deviation of 3.42. The mean difference was 11.1 and the paired ' $t$ ' test value was 39.32. Child to child program through power point presentation was effective to increase the knowledge at ' $p$ ' value was $<0.001$.

There was a significant association between the post test level of knowledge among school children and their selected demographic variables like age $(0.0000992)$ and grade of child $(0.00759)$ and clinical variables like previous knowledge (0.0067) with post test level of knowledge.

\section{CONCLUSION:}

Based on the findings of the study, the score on knowledge regarding ill effects of television watching has been increased. This implied that child to child program has significant effect on increasing the knowledge among the school children.

\section{REFERENCES:}

1) Dorothy R. Bardara A. Text Book of Paediatric Nursing. India: Elsevier publication; 2004.

2) Dutta. P. Paediatric Nursing. New Delhi. Jaypee Brothers Medical Publishers: 2009.

3) Ghai. O. P. Essential Paediatrics. New Delhi. Interprint publishers: 2006.

4) Wong's. Essential of Paediatric Nursing. Elsevier Publications. 2010.

5) http://ncbi.nlm.nih.gov/pmc/articles.com

6) http://childcare /article

7) http://www.ons.org/publications/ONF/features/ media/artice 